Limnol. Rev. (2014) 14,2: 101-108

\title{
Oxidative response of wetland macrophytes in response to contaminants of abiotic components of East Kolkata wetland ecosystem
}

\author{
Sudin Pal $^{1,4}$, Priyanka Mondal ${ }^{2}$, Subhajit Bhar ${ }^{3}$, Buddhadeb Chattopadhyay ${ }^{4}$, Subhra Kumar Mukhopadhyay ${ }^{5}$ \\ ${ }^{1}$ Department of Conservation Biology, Durgapur Government College, Durgapur-713214, India, \\ e-mail: sudindgp1@gmail.com (corresponding author) \\ ${ }^{2}$ Department of Zoology, Bethune College, Kolkata-700006, India, e-mail: mpriyanka0407@gmail.com \\ ${ }^{3}$ Department of Environmental Sciences, University of Kalyani, Nadia-741235, India, e-mail: subhojitbhor@gmail.com \\ ${ }^{4}$ Government College of Engineering and Leather Technology, Kolkata-700098, India, e-mail: cbuddhadeb@gmail.com \\ ${ }^{5}$ Hooghly Mohsin College, Chinsurah, Hooghly-712101, India, e-mail: subhro22@gmail.com
}

\begin{abstract}
The tannery effluent and composite municipal sewage water drained to the East Kolkata wetland (EKW), a Ramsar Site (1208), is used for agriculture and pisciculture after natural stabilization. Such composite wastewater is characterized by exceedingly high total dissolved solids, total hardness, chloride and heavy metals concentrations. These water born pollutants generate reactive oxygen species which are potentially toxic to the biological system. These reactive oxygen species are normally detoxified by some enzymes, such as superoxide dismutase (SOD) and catalase (CAT). The present study was commenced to find out the SOD and CAT activities against the oxidative stress, if any, in four macrophytes namely, Eichhornia crassipes, Pistia stratiotes, Alternanthera sessilis and Sagittarria montevidensis of contaminated ponds (Site 1 and Site 2) of EKW and an uncontaminated site (Control site). During the course of sampling the physico-chemical factors were found significantly higher in the EKW ponds compared to the control site. In the EKW sites, higher rate of evaporation during summer months caused higher elemental concentration in the premonsoon than in other seasons. This led to high activity of both SOD and CAT enzymes. In contrast, heavy rain fall in monsoon lowers the elemental concentration - mainly due to dilution effect. Present experiment indicated that in a stressed ecosystem like EKW, the wetland plants overcome the stress by altering their stress enzyme activities, hence suggesting an evidence of adaptive mechanism to thrive in a stressful environment.
\end{abstract}

Key words: East Kolkata Wetland Ecosystem, tannery effluent, oxidative stress, superoxide dismutase, catalase

\section{Introduction}

The pollutant generated from different anthropogenic activities interferes with the physiological functions of the exposed biota. These pollutants produce reactive oxygen species such as superoxide radical $\left(\mathrm{O}_{2}^{-}\right)$, hydroxyl radical $(\cdot \mathrm{OH})$, hydrogen peroxide $\left(\mathrm{H}_{2} \mathrm{O}_{2}\right)$ and alkoxyl radical (RO.) within the living system (Gallego et al. 1996; Weckx and Clijsters 1997; Loggini et al. 1999; Panda and Patra 2000; Bakardjieva et al. 2000; Hernandez et al. 2000). These reactive oxygen species pose a great threat to the living organisms, owing to their toxicity. Therefore, the living organisms, which thrive in polluted areas, adopt the antioxidative defense system to protect themselves from the effect of reactive oxygen species. Effects of different hazardous contaminants, which produce reactive oxygen species, and their bioaccumulation and biomagnifications in different organisms of wetland ecosystem, are amply studied. It is well known that waste elements including the heavy metals are one of the major pollutants in water bodies. These heavy metals are entered into the food chain, resulting in further contamination of biota (Rzymski et al. 2013). However, little work has been done on the response of antioxidant enzyme activities in wetland plants, in presence of significantly high amount of waste elements and heavy metals. The generation of active oxygen and the consequent change in the level of antioxidant enzyme activity in Hydrilla verticillata under $\mathrm{Cd}, \mathrm{Cu}$ and $\mathrm{Zn}$ stress were investi- 
gated and the results showed that these three metals accelerated the generation rate of enzyme to a certain extent (Xu et al. 2006). Phytochelatins and antioxidant systems response to arsenic stress in Hydrilla verticillata were examined and showed predominant stimulation of antioxidant enzyme activity (Srivastava et al. 2007). The effect of increased ammonia content on sub-acute biochemical responses were assessed in the rooted submerged aquatic macrophyte Myriophyllum mattogrossense and the results showed that ammonia was able to generate oxidative stress, expressed through an enhancement of catalase, guaiacol peroxidase, glutathione peroxidase and glutathione S-transferase activities (Nimptsch and Pflugmacher 2007). The biochemical contents and enzyme activities of water lettuce showed a great variation with respect to the increase in chromium concentrations (Ganesh et al. 2007). Cavas and Yurdakoc (2005) assessed the antioxidant system in the invasive green alga Caulerpa racemosa and some macrophytes from the Mediterranean. Lizieri et al. (2012) studied the morpho-physiological responses of free-floating aquatic macrophytes to a supra-optimal supply of manganese. Rout and Shaw (2000a, 2000b, 2001) studied the solt tlarence of aquatic macrophytes and the possible involvement of the antioxidant enzymes on them. Dazy et al. (2009) studied the possibilities of use of antioxidant stress enzymes as biomarkers associated with heavy metal stress. However, in the context of Indian wetland plants, a few studies have been done and such works from the contaminated EKW (Ramsar site; no. 1208) is altogether absent. Therefore, in the present investigation, the foremost objective was to find out the antioxidant activities (SOD and CAT) against oxidative stress, if any, in four macrophytes viz. Eichhornia crassipes, Pistia stratiotes, Alternanthera sessilis and Sagittarria montevidensis and secondly, the temporal variations in enzyme activities were recorded in the above mentioned macrophytes thriving in EKW areas to identify their potential role as biomarkers.

\section{Study site description}

EKW comprises a total area of 12,741 ha out of which the water spread area is 4728 ha, degraded water spread area is 1124 ha, agricultural land is 4959 ha, garbage farming area is 602 ha and urban and rural settlement cover 1326 ha approximately (Pal et al. 2013). The water, soil and plant samples were collected from three distinct study sites. The first sampling sta- tion, Site 1 ( $22^{\circ} 32^{\prime} 27.7^{\prime \prime} \mathrm{N}, 8^{\circ} 24^{\prime} 18.3$ ” E; area 0.16 hector and mean depth 1 meter) was a tannery effluentfed fish pond. Site $2\left(22^{\circ} 32^{\prime} 3.71^{\prime \prime} N\right.$, 88 $8^{\circ} 28^{\prime} 57.51^{\prime \prime} \mathrm{E}$; area 0.13 ha and mean depth 1.5 meter) was a composite wastewater-fed (municipal and industrial wastewater) fish pond of EKW. The uncontaminated water body (Fulpukur; 22 $53^{\prime} 30^{\prime \prime} \mathrm{N}, 88^{\circ} 23^{\prime} 50^{\prime \prime} \mathrm{E}$; area 0.11 ha and mean depth 1.5 meter) was selected as a control site, located in Chinsurah, Hooghly district, West Bengal, India.

\section{Material and Methods}

\section{Sample Collection}

Sampling was done fortnightly during MarchMay (Pre-monsoon/PreM), July-September (Monsoon/Mon) and November-January (Post-monsoon/ PostM) and the mean month-wise data was presented. Water samples were collected in clean stopper plastic bottles $\left(1 \mathrm{dm}^{3}\right)$ by immersing them completely into the water. For heavy metal analysis, water samples were preserved separately in a $500 \mathrm{~cm}^{3}$ bottle and acidified with nitric acid ( $\mathrm{pH}$ less than 2.0). The preselected four wetland plants, namely, Eichhornia crassipes, Pistia stratiotes, Alternanthera sessilis and Sagittarria montevidensis were collected from above mentioned sites and their leaves were preserved in an ice box and were quickly transported (within half-an-hour after collection) to the laboratory for enzyme analysis. In laboratory, the samples were stored in $20^{\circ} \mathrm{C}$ refrigeration and for elemental analysis the plants samples were cut into small pieces and dried in a hot-air oven at $70^{\circ} \mathrm{C}$ for 12 hours.

\section{Sample analysis}

Physico-chemical factors and elemental analysis of water samples: All gravimetric analysis, reagents and standard preparations were made using Mettler AE 240 monopan electronic balance. The physicochemical factors like $\mathrm{pH}$, Conductivity (COND), Total Dissolve Solids (TDS), Salinity (SAL) were measured by Eutech 5-in-1 Multiparameter PCS Tester 35. Acidity (ACID), alkalinity (ALK), Total Hardness (THARD) and Carbonate Hardness (CHARD) were measured by Aquamark (Germany) water testing kits and all the chemicals used in this experiment were from Merck, Germany.

Concentration of all the elements like Chromium (Cr), Manganese (Mn), Iron (Fe), Copper $(\mathrm{Cu})$, Zinc $(\mathrm{Zn})$ and Lead $(\mathrm{Pb})$ estimation were measured 
by Atomic Absorption Spectrophotometer (PerkinElmer AAnalyst-100) and Chloride (Cl), Nitrate $\left(\mathrm{NO}_{3}\right)$ and Phosphate $\left(\mathrm{PO}_{4}\right)$ were analyzed by Metrohm 761 Ion exchange chromatograph. The samples were prepared and analyzed following the protocols laid by Eaton et al. (1995) and Jackson (2000).

\section{Enzyme Assay}

Plant samples were cut into small pieces. $0.5 \mathrm{~g}$ plant samples were grounded with liquid nitrogen and then $4 \mathrm{ml}$ phosphate buffer $(0.1 \mathrm{M}$ with $\mathrm{pH} 6.8)$ containing 10\% Ploy Vinyl Pyrrolidone was mixed with it. The samples were then taken in the Ependrops and were centrifuged at $15000 \mathrm{rpm}$ in cold centrifuge (Remi) for 30 minutes. In order to determine the SOD activity in plant tissue, enzyme assay was performed following the method proposed by Paoletti et al. (1986). To make the Tea-Dea buffer for the process $100 \mathrm{mM}(14.9 \mathrm{~g})$ Tri-Ethanol Amine (Tea) and $100 \mathrm{mM}(10.5 \mathrm{~g})$ Di Ethanol Amine (Dea) and $13.8 \mathrm{~cm}^{3}$ of $37 \%$ hydrochloric acid were mixed and the volume was made up to 1liter with water. The $\mathrm{pH}$ of the buffer was maintained 7.4. Also to make $10 \mathrm{mM} \beta$ Marcaptoethanol, $14.2 \mathrm{M} 0.05 \mathrm{~cm}^{3}$ of concentrated Thiol was diluted with water up to $71 \mathrm{~cm}^{3}$. For the SOD assay 0.8 $\mathrm{cm}^{3}$ Tea Dea buffer was mixed with $0.4 \mathrm{~cm}^{3} \mathrm{NADH}$ (7.5mM), $0.025 \mathrm{~cm}^{3}$ EDTA- $\mathrm{MnCl}_{2}$ (EDTA/ $\mathrm{MnCl}_{2}-$ $100 \mathrm{mM} / 50 \mathrm{mM}), 0.1 \mathrm{~cm}^{3}$ plant extract and $0.1 \mathrm{~cm}^{3} \beta$ Marcaptoethanol (10mM). To know the SOD concentration the mixture was measured at $650 \mathrm{~nm}$ by UVVisual spectrophotometer (Perkin Elmer Lamda 25) against a blank (phosphate buffer instead of sample). The assay of CAT was done by the method proposed by Aebi (1984). $2 \mathrm{~cm}^{3}$ plant extract was mixed with 1 $\mathrm{cm}^{3} \mathrm{H}_{2} \mathrm{O}_{2}(30 \mathrm{mM})$ and the absorbance was measured at $240 \mathrm{~nm}$ using the UV-Visual spectrophotometer (Perkin Elmer Lamda 25) against a blank containing $1 \mathrm{ml}$ phosphate buffer instead of $\mathrm{H}_{2} \mathrm{O}_{2}$ and plant sample. The protein content of the plant extract was estimated by following the method proposed by Lowry et al. 1951.

\section{Statistical Analysis}

Analysis of variance (ANOVA) was performed on the data of the enzyme activities in macrophyte tissues to test for the significant differences between site-wise (uncontaminated and contaminated) as well as for season-wise variability. Statistical analyses were performed using Statistica for Windows (version 5.1 A). Graphical representations from the obtained data were prepared using Origin version 6.1 software.

\section{Results}

In order to establish the nature and extent of physico-chemical stress on the macrophytes seventeen parameters of water were compared among two contaminated and one uncontaminated pond. The spatial and temporal changes of the physicochemical parameters of pond water are illustrated in Table 1. The tannery wastewater that was used in Site- 1 contains various chemicals. These chemicals were used at the time of tannery operations. The composite municipal wastewater used in Site 2, also contains different chemicals from industry, detergent from households and pesticides from agricultural runoff. Thus the trend Site $1>$ Site 2 $>$ control, was found for all physico-chemical parameters except for the $\mathrm{pH}$. $\mathrm{pH}$ was slightly lower in Site 1 than Site 2 and control. Due to high temperature and evaporation the conductivity, TDS and SAL were high in pre-monsoon in all the three sites and due to heavy rainfall in monsoon the water got diluted so all those components were lowered down. The same pattern was also seen in ALK, THARD, CHARD, $\mathrm{Cl}, \mathrm{NO}_{3}$ and $\mathrm{PO}_{4}$ and in all heavy metals ( $\mathrm{Cr}, \mathrm{Mn}, \mathrm{Fe}, \mathrm{Cu}, \mathrm{Zn} \mathrm{Pb})$ concentrations (Table 1). The one way ANOVA was executed based on the physico-chemical parameters to reveal the differences between control site and two contaminated sites. The COND, TDS, SAL, THARD, CHARD, Mn, Zn were higher in Site 1 pond of EKW than the control pond (Table 1).

In contrast to control site, the activity of SOD and CAT in macrophytes were significantly (at $\mathrm{P}<$ 0.05) high in Site 1 and Site 2 (Fig. 1). Among the four macrophytes, the Sagittarria montevidensis (Fig. $1 \mathrm{~g}$ ) showed the highest activity of stress enzyme in the contaminated sites at premonsoon seasons. Likewise the Alternanthera sessilis (Fig. 1e) showed the highest activity in uncontaminated site at the same season. In the premonsoon the SOD activity was highest in Sagittarria montevidensis among the four macrophytes of both contaminated sites (Fig. 1g) and in Alternanthera sessilis of control site (Fig. 1e). On the contrary, the SOD activity in Eichhornia crassipes was found to be highest in all sites at monsoon and postmonsoon seasons (Fig. 1a). In case of CAT activity, Eichhornia crassipes showed the highest value in Site 1 and Control site at premonsoon and monsoon (Fig. 1a). At the same time CAT activity was highest in Alternanthera sessilis at Site 2 (Fig. 1f). The CAT activity was high in Pistia stratiotes of Site 1 (Fig. 1d) and Alternanthera sessilis of Site 2 and control site in post monsoon (Fig. 1f). 
Table 1. Temporal variation of physico-chemical parameters of water in Site 1, Site 2, and Control site. The mean value of Control site marked with „a” for Site 1 and „b” for site 2 are significantly lower than Site 1 and Site 2 in one-way ANOVA at p<0.05; BDL= Below Detection Limit (Detection Limit $0.01 \mathrm{mg} \mathrm{dm}^{-3}$ )

\begin{tabular}{|c|c|c|c|c|c|c|c|c|c|c|c|c|}
\hline \multirow{2}{*}{ Parameter } & \multicolumn{3}{|c|}{ Premonsoon } & \multicolumn{3}{|c|}{ Monsoon } & \multicolumn{3}{|c|}{ Postmonsoon } & \multirow{2}{*}{$\begin{array}{l}\text { Site } 1 \\
\text { Mean }\end{array}$} & \multirow{2}{*}{$\begin{array}{l}\text { Site } 2 \\
\text { Mean }\end{array}$} & \multirow{2}{*}{$\begin{array}{c}\text { Control } \\
\text { Mean }\end{array}$} \\
\hline & Site 1 & Site 2 & Control & Site 1 & Site 2 & Control & Site 1 & Site 2 & Control & & & \\
\hline $\mathrm{pH}$ & 7.93 & 8.21 & 8.5 & 7.92 & 8.23 & 7.6 & 8.15 & 8.28 & 8.2 & 8.00 & 8.24 & 8.1 \\
\hline $\mathrm{ACID}\left[\mathrm{mmol} \mathrm{dm}{ }^{-3}\right]$ & 0.3 & 0.37 & 0.3 & 0.2 & 0.22 & 0.4 & 0.1 & 0.17 & 0.2 & 0.2 & 0.25 & 0.3 \\
\hline $\mathrm{ALK}\left[\mathrm{mmol} \mathrm{dm}{ }^{-3}\right]$ & 17.2 & 5.2 & 4.5 & 10.37 & 7.4 & 3.9 & 10.75 & 7.22 & 4.7 & 12.7 & 6.60 & 4.36 \\
\hline COND $\left[\mu \mathrm{S} \mathrm{cm}^{-1}\right]$ & 5925 & 2707.5 & 523 & 3240.5 & 1894.7 & 495 & 4680 & 1833.5 & 682 & 4615.1 & 2145.2 & $566.6^{a}$ \\
\hline TDS [ppm] & 4207.5 & 1935 & 412 & 2502.5 & 1264.5 & 357 & 3315 & 1302.5 & 509 & 3341.6 & 1500.6 & $426^{a}$ \\
\hline SAL [ppm] & 3325 & 1402.5 & 301 & 1711.5 & 921.75 & 241 & 2490 & 922.7 & 388 & 2508.8 & 1082.3 & $310^{a}$ \\
\hline THARD [mg dm-3] & 1068.3 & 416.59 & 212.5 & 798.3 & 378.1 & 175.9 & 797.44 & 403.17 & 267.4 & 888.0 & 399.28 & $218.6^{a, b}$ \\
\hline CHARD [mg dm$\left.{ }^{-3}\right]$ & 1064.3 & 315.49 & 187.1 & 653.4 & 308.6 & 155.2 & 710.22 & 315.06 & 202.8 & 809.3 & 313.05 & $181.7^{a}$ \\
\hline $\mathrm{Cl}\left[\mathrm{mg} \mathrm{dm}^{-3}\right]$ & 2490.2 & 864.01 & 167.67 & 953.63 & 506.92 & 94.68 & 1704.7 & 529.37 & 160.49 & 1716.2 & 633.43 & 140.9 \\
\hline $\mathrm{NO} 3\left[\mathrm{mg} \mathrm{dm}^{-3}\right]$ & 3.61 & 1.96 & 0.77 & 15.18 & 11.19 & 6.79 & 1.34 & 5.94 & 0.86 & 6.7 & 6.36 & 2.81 \\
\hline $\mathrm{PO} 4\left[\mathrm{mg} \mathrm{dm}^{-3}\right]$ & 2.35 & 1.82 & 0.04 & 11.39 & 8.62 & 0.07 & 3.09 & 2.09 & 0.15 & 5.6 & 4.18 & 0.09 \\
\hline $\mathrm{Cr}\left[\mathrm{mg} \mathrm{dm}^{-3}\right]$ & 0.5 & 0.08 & BDL & 1.2 & 0.55 & BDL & 2.27 & 0.425 & BDL & 1.3 & 0.35 & BDL \\
\hline $\mathrm{Mn}\left[\mathrm{mg} \mathrm{dm}^{-3}\right]$ & 2.83 & 1.1 & 0.32 & 1.7 & 1.85 & 0.21 & 2.5 & 0.5 & 0.25 & 2.3 & 1.15 & $0.26^{a}$ \\
\hline $\mathrm{Fe}\left[\mathrm{mg} \mathrm{dm}^{-3}\right]$ & 2.7 & 1.5 & 0.63 & 0.1 & 0.42 & 0.48 & 0.4 & 0.97 & 0.55 & 1.06 & 0.96 & 0.55 \\
\hline $\mathrm{Cu}\left[\mathrm{mg} \mathrm{dm}^{-3}\right]$ & 0.23 & 0.09 & BDL & 0.02 & 0.57 & BDL & BDL & BDL & BDL & 0.08 & 0.22 & BDL \\
\hline $\mathrm{Zn}\left[\mathrm{mg} \mathrm{dm}^{-3}\right]$ & 6.45 & 5.25 & 1.1 & 4.72 & 4.27 & 0.48 & 4.62 & 3.07 & 0.67 & 5.26 & 4.2 & $0.75^{\mathrm{a}}$ \\
\hline $\mathrm{Pb}\left[\mathrm{mg} \mathrm{dm}^{-3}\right]$ & 0.57 & 0.33 & BDL & 1.17 & 0.77 & $\mathrm{BDL}$ & 0.2 & $\mathrm{BDL}$ & $\mathrm{BDL}$ & 0.64 & 0.36 & $\mathrm{BDL}$ \\
\hline
\end{tabular}

In temporal scale the species wise SOD activity was highest in premonsoon followed by monsoon and postmonsoon. The same trend was shown in the case of CAT activity, few exception was caused due to some spatial interference like - in case of Pistia stratiotes of Site 1 in postmonsoon, in Alternanthera sessilis of site 2 in monsoon, in Sagittarria montevidensis of Site 2 and Control site in postmonsoon (Fig. 1d,f and h). Except SOD activity in Pistia stratiotes of site 1 and site 2, in all the three sites the stress enzyme activity showed significant seasonal variation (at $\mathrm{P}<0.01$ ) in all of the four selected macrophytes (Table 2). Analyzing the results it was revealed that in all four macrophytes of the three sites, the activities of SOD and CAT were significantly (at $\mathrm{P}<0.01$ ) different (Table 2 ).

\section{Discussion}

The physical and chemical factors of a water body if exceeds the threshold level causes some stress to its biome. The imbalance between production and elimination of the active oxygen is often caused by many chemicals (XU Qin-Song et al. 2006). The anti- oxidant enzyme such as SOD and CAT protect the tissues against the reactive oxygen species. The water quality of the ponds (here Site 1 and Site 2) of EKW get degraded due to the waste feeding from tannery industry and composite municipal discharge. Whereas in the control site no such input of waste products occur. So, the factors such as COND, TDS, SAL, THARD are significantly high in both sites of EKW compared to the control site. In addition the higher concentration of heavy metals in the contaminated sites stimulates the oxidative stress in the wetland macrophytes (Table 1).

The SOD and CAT provide the first defense line against oxygen toxicity in individuals. Generally in an oxidative stress condition the SOD catalyzes dismutation of superoxide radical which in turn forms water and hydrogen peroxide. After that hydrogen peroxide being the substrate, it gets detoxified by CAT. The present study indicates that higher activity of SOD and CAT in macrophytes collected from contaminated sites of EKW is higher than the control site. (Figure 1: a-h). This clearly indicates that the enhanced production of superoxide radicals create an oxidative stress to the macrophytes. 

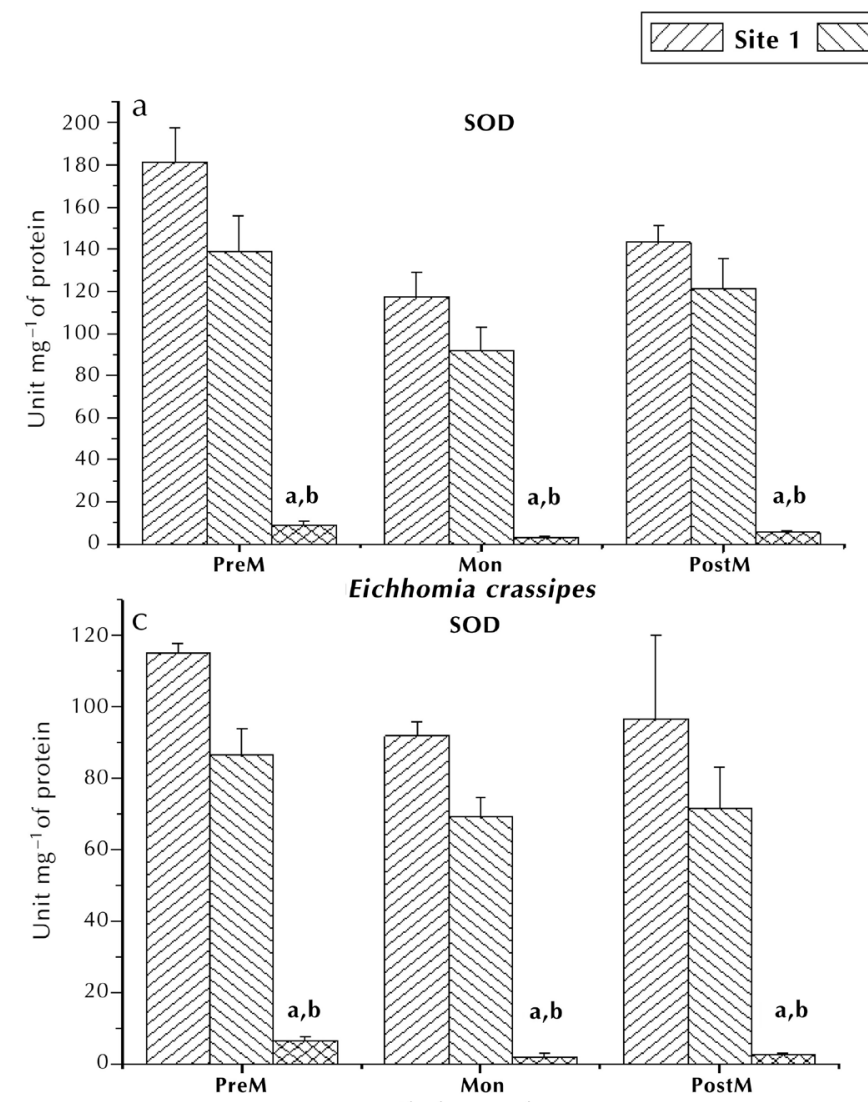

Site $2 \times X X$ Control
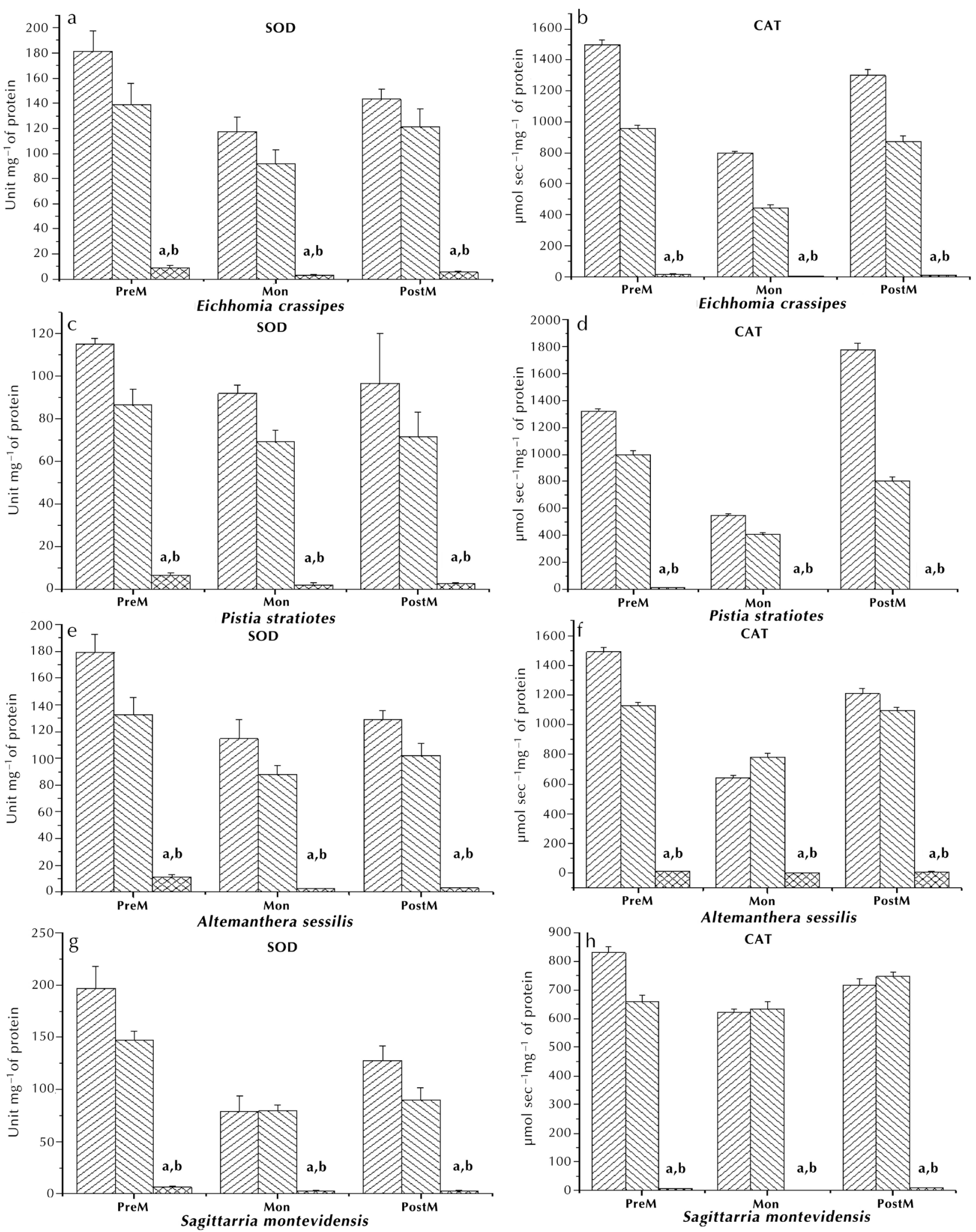

Fig. 1. Temporal variation in the activities of Superoxide dismutase and catalase in four selected macrophytes thriving in Site 1, Site 2 and Control (Fulpukur Pond). The bars marked with „a” indicate the differences between Site 1 and Control Site, and marked with „b” indicate the differences between Site 2 and Control Site are significant at $p<0.05$ 
Table 2. One way ANOVA Results Indicating Significant of Season-Wise Variation and Species Specific Variations between the Selected Ponds. Values marked with asterysk $\left(^{*}\right)$ are significant at $\mathrm{p}<0.01$

\begin{tabular}{|c|c|c|c|c|}
\hline \multicolumn{5}{|c|}{ Seasonal Variations } \\
\hline Ponds & Enzymes & \multicolumn{2}{|c|}{ Macrophytes Species } & F value \\
\hline \multirow{4}{*}{ Site 1} & \multirow{4}{*}{ SOD } & \multicolumn{2}{|l|}{ E. crassipes } & $24.531^{*}$ \\
\hline & & \multicolumn{2}{|l|}{ P. stratiotes } & 3.0170 \\
\hline & & \multicolumn{2}{|l|}{ A. sessilis } & $30.250^{*}$ \\
\hline & & \multicolumn{2}{|c|}{ S. montevidensis } & 109.009* \\
\hline \multirow{4}{*}{ Site 1} & \multirow{4}{*}{ Catalase } & \multicolumn{2}{|c|}{ E. crassipes } & $41.455^{*}$ \\
\hline & & \multicolumn{2}{|l|}{ P. stratiotes } & $328.067^{*}$ \\
\hline & & \multicolumn{2}{|l|}{ A. sessilis } & $110.014^{*}$ \\
\hline & & \multicolumn{2}{|c|}{ S. montevidensis } & $7.689^{*}$ \\
\hline \multirow{4}{*}{ Site 2} & \multirow{4}{*}{ SOD } & \multicolumn{2}{|l|}{ E. crassipes } & $34.560^{*}$ \\
\hline & & \multicolumn{2}{|l|}{ P. stratiotes } & 1.1524 \\
\hline & & \multicolumn{2}{|l|}{ A. sessilis } & $10.6181^{*}$ \\
\hline & & \multicolumn{2}{|c|}{ S. montevidensis } & $67.991^{*}$ \\
\hline \multirow{4}{*}{ Site 2} & \multirow{4}{*}{ Catalase } & \multicolumn{2}{|l|}{ E. crassipes } & $76.516^{*}$ \\
\hline & & \multicolumn{2}{|l|}{ P. stratiotes } & $82.766^{*}$ \\
\hline & & \multicolumn{2}{|l|}{ A. sessilis } & $36.619^{*}$ \\
\hline & & \multicolumn{2}{|c|}{ S. montevidensis } & $5.994^{*}$ \\
\hline \multirow{4}{*}{ Control } & \multirow{4}{*}{ SOD } & \multicolumn{2}{|l|}{ E. crassipes } & $11.8888^{*}$ \\
\hline & & P. stratiotes & & $8.1881^{*}$ \\
\hline & & A. sessilis & & $19.0189^{*}$ \\
\hline & & S. monteviden & & $17.3251^{*}$ \\
\hline & & E. crassipes & & $10.9789^{*}$ \\
\hline Control & Catalace & P. stratiotes & & $116.1389^{*}$ \\
\hline क्षाता & Lataiase & A. sessilis & & $15.4299^{*}$ \\
\hline & & S. monteviden & & $18.1006^{*}$ \\
\hline & & ecies Specific & ariations & \\
\hline Pondc & Enzumpc & & F Value & \\
\hline क्षापि & Liा<ymes & Premonsoon & Monsoon & Postmonsoon \\
\hline Sito 1 & SOD & $294.704^{*}$ & $72.074^{*}$ & $72.036^{*}$ \\
\hline ( & Catalase & $184.857^{*}$ & $192.722^{*}$ & $559.002^{*}$ \\
\hline Site 2 & SOD & $258.350^{*}$ & $67.668^{*}$ & $70.160^{*}$ \\
\hline VItट & Catalase & $199.084^{*}$ & $274.119^{*}$ & $660.05^{*}$ \\
\hline Control & SOD & $298.944^{*}$ & $89.345^{*}$ & $75.572^{*}$ \\
\hline - & Catalase & $257.830^{*}$ & $427.703^{*}$ & 820.054 * \\
\hline
\end{tabular}

Compared to the monsoon and postmonsoon the concentration of heavy metals and other limnological parameters are high in premonsoon due to the high evaporation rate. In monsoon, due to heavy rainfall and runoff water, the tannery waste water and composite municipal sewage water get diluted and as a result the concentration of all the heavy metals and other chemical factors are reduced considerably. This trend is also observed in the case of the control site. Owing to the dilution of pond water in monsoon the stress is reduced significantly, which reflects to the reduction of SOD and CAT activity in the four selected macrophytes. Only in the case of CAT activity in monsoon of A. sessilis and S. montevidensis is comparatively high in Site 2 . This may be due to the higher concentration of $\mathrm{Mn}, \mathrm{Fe}, \mathrm{Cu}$ in Site 2 in monsoon.

The SOD and CAT activities in four different plants, thriving in EKW and control site get varied according to the environment factors. That means they have their innate capability to protect their physiological system against the adverse effects of reactive oxygen species. From the present study it is observed that in response of contaminants the SOD activity is the highest in E. crassipes followed by A. sessilis, $S$. montevidensis and P. stratiotes in all sites. Whereas the gradient for the CAT in Site 1 is $P$. stratiotes $>E$. crassipes $>$ A. sessilis $>S$. montevidensis, for Site 2 it is A. sessili $s>$ E. crassipes $>P$. stratiotes $>S$. montevidensis and for control site it is E. crassipes $>A$. sessilis $>S$. montevidensis $>$ P. stratiotes. So, the responses of macrophytes against the contaminants are different and it is due to the morphological and physiological differences among the selected macrophytes and as a result the amounts of generation of reactive oxygen species are varied. On the other hand, from this comparative study it is possible to correlate the levels of pollution and induction of antioxidant enzymes. Finally, it is suggested from the study that the SOD and CAT activities in plants can be considered as a sensitive biomarker for monitoring the wetland environment.

\section{Acknowledgement}

First author thankfully acknowledges INSPIRE Division, Department of Science and Technology, Ministry of Science and Technology, Govt. of India for providing the INSPIRE Fellowship along with contingency grants. The authors are also thankful to Dr. Anjan Biswas, Assoc. Professor of Leather Technology, Govt. College of Engg. \& Leather Tech. for his kind cooperation and support and Dr. Abhishek Roy Goswami, Dr. Anulipi Aich and Mr. Shiddharta Sankar Ram for their valuable help on this work. 


\section{References}

Aebi H., 1984, Catalase in vitro: Methods in Enzymology, [in:] Packer L. (ed.), Oxygen Radicals in Biological Systems, Acad. Press, Orlando: 121-126.

Barkasdjieva N.T., Chrostov K.N., Christina K.N., 2000, Effect of calcium and zinc on the acivity and thermostability of superoxide dismutase, Biol. Plant 43: 73-78.

Bowler C., Montagu M.V., Inze D., 1992, Superoxide dismutase and stress tolerance, Ann. Rev. Plant Physiol. Plant Mol. Biol. 43: 83-116.

Casano L., Gomez L., Lascano C., Trippi V., 1997, Inactivation and degradation of $\mathrm{Cu} / \mathrm{ZnSOD}$ by active oxygen species in wheat chloroplasts exposed to photooxidative stress, Plant Cell Physiol. 38: 433-440.

Cavas L., Yurdakoc K., 2005, A comparative study: Assessment of the antioxidant system in the invasive green alga Caulerpa racemosa and some macrophytes from the Mediterranean, J. Exp. Mar. Biol. Ecol. 321(1): 35-41.

Chatterjee S., Chattopadhyay B., Mukhopadhyay S.K., 2006, Trace metal distribution in tissues if cichlids (Oreochromis niloticus and O. mossambicus) collected from wastewater-fed fishponds in East Calcutta wetlands, a Ramsar site, Acta Ichthyol. Piscat. 36(2): 119-1250.

Chattopadhyay B., Chatterjee A., Mukhopadhyay S.K., 2002, Bioaccumulation of Metals in the East Calcutta Wetland Ecosystem, Aquat. Ecosyst. Health Manage. 5(2): 191203.

Chattopadhyay B., Chatterjee A., Mukhopadhyay S.K., 2004, Seasonality in physico-chemical parameters of tannery wastewater passing through the East Calcutta wetland ecosystem, J. Soc. Leather Tech. Chem. 88(1): 27-36.

Chongpraditnum P., Mori S., Chino M., 1992, Excess copper induce a cytosolic $\mathrm{Cu}, \mathrm{Zn}$ superoxide dismutase in soybean root, Plant Cell Physiol. 33: 239-244.

Dazy M., Masfaraud J.F., Ferard J.F., 2009, Induction of oxidative stress biomarkers associated with heavy metal stress in Fontinalis antipyretica, Chemosphere 75: 297302.

Dixit V., Pandey V., Shyam R., 2001, Differential antioxidative responses to cadmium in roots and leaves of pea ( $P i$ sum sativum L. cv. Azad), J. Exp. Bot. 52: 1101-1109.

Eaton A.D., Clesceri L.S., Greenberg A.E., 1995, Standerd Methods of the Examination of Water and Wastewater, $19^{\text {th }}$ Edition, APHA, Washington.

Gallego S.M., Benavides M.P., Tomaro M.L., 1996, Effect of heavy metal ion excess on sunflower leaves: evidence for involvement of oxidative stress, Plant Sci. 121: 151-159.

Ganesh S.K., Baskaram L., Rajasekram S., Sumathi K., Chidambaram A.L.A., Sundormurty P., 2008, Chromium stress induced alterations in biochemical and enzyme metabolism in aquatic and terrestrial plants, J. Coll. Surf. B: Biointerfaces 63(2): 159-163.

Giannopolitis C.N., Reis S.K., 1997, Superoxide dismutase I. Occurrence in higher plants, Plant Physiol. 59: 309-314.
Grant J.J., Loake G.J., 2000, Role of active oxygen intermediates and cognate redox signaling in disease resistance, Plant Physiol. 124: 21-29.

Hernandez J.A., del Rio L.A., Sevilla F., 1994, Salt stress induced changes in superoxide dismutase isozymes in leaves and mesophyll protoplasts from Vigna radiata (L.) Walp., New Phytol. 126: 37-44.

Jackson P.E., 2000, Ion Chromatography in environmental analysis, [in:] Mayers R.A. (ed.), Encyclopedia of Analytical Chemistry, Wiley, Chichester: 2779-2801.

Kanematsu S., Asada K., 1989, Cu/Zn superoxide dismutase in rice: occurrence of an active, monomeric enzyme and non-photosynthetic tissue, Plant Cell Physiol. 30: 381-391.

Levitt J., 1980, Plant Responses to Environmental Stress, Acad. Press, London, p. 497.

Lizieri C., Kuki K.N., Aguiar R., 2012, The morphophysiological responses of free-floating aquatic macrophytes to a supra-optimal supply of manganese, Water Air Soil Poll. 223(5): 2807-2820.

Navari-Izzo F., Quartracci M., Sgherri C., 1997, Dessication tolerance in higher plants related to free radical defences, Phyton 37: 203-214.

Nimptsch J., Pfugmacher S., 2007, Ammonia triggers the promotion of oxidative stress in the aquatic macrophyte Myriophyllum mattogrossense, Chemosphere 66(4): 708-14.

Pal S., Chattopadhyay B., Mukhopadhyay S.K., 2013, Variability of carbon content in water and sediment in relation with physico-chemical parameters of East Kolkata Wetland Ecosystem: A Ramsar Site 1208, NeBIO 4(6): 70-75.

Panda S.K., Patra H.K., 2000, Does chromium (III) produce oxidative stress in excised wheat leaves? J. Plant Biol. 27: 105-110.

Paoletti F., Aldinucci D., Mocali A., Caparrini A.A., 1986, Sensitive spectrophotometric method for the dtermination of superoxide dismutase activity in tissue extracts, Anal. Biochem. 154: 564-541.

Rout N.P., Shaw B.P., 2000a, Salt tolerance in aquatic macrophytes : possible involvement of the antioxidant enzymes, Plant Sci. 160: 415-423.

Rout N.P., Shaw B.P., 2000b, Salt tolernace in aquatic macrophytes: ionic relation and interaction, Biol. Plant 44:9599.

Rout N.P., Shaw B.P., 2001, Salt tolerance in aquatic macrophytes: possible involvement of the antioxidative enzymes, Plant Sci. 160(3): 415-423.

Rzymski P., Klimaszyk P., Niedzielski P., Poniedziałek B., 2013, Metal accumulation in sediments and biota in Malta Reservoir (Poland), Limnol. Rev. 13(3): 163-169.

Scandalios J.G., 1993, Oxygen stress and superoxide dismutase, Plant Physiol. 101: 7-12.

Smirnoff N., 1993, The role of active oxygen in response to water deficit and dessication, New Phytol. 125: 27-58. 
Xu Q.-S., Shi G.-X., Wang X., Wu G.-R., 2006, Generation of active oxygen and change of antioxidant enzyme activity in Hydrilla verticillata under $\mathrm{Cd}, \mathrm{Cu}$ and $\mathrm{Zn}$ stress, Acta Hydrobiol. Sinica 30(1): 107-112.

Srivastava S., Mishra S., Tripathi R.D., Dwivedi S., Trivedi P.K., Tandon P.K., 2007, Phytochelatins and antioxidant systems respond differentially during arsenite and arsenate stress in Hydrilla verticillata (L.f.) Royle, Environ. Sci.Tech. 41(8): 2930-6.
Weckx J.E.J., Ciljsters H.M., 1997, Zn phytotoxicity induces oxidative stress in primary leaves of Phaseolus vulgaris L., Plant Physiol. Biochem. 35: 405-410.

Zhang J., Kirkham M.B., 1994, Drought-stress induced changes in activities of superoxide dismutase, catalase and peroxidases in wheat leaves, Plant Cell Physiol. 35: 785-791. 